\title{
Effects of using Stone Dust and GGBS in Concrete
}

\author{
Gokulapadu Azmathulla ${ }^{1}$, T Vinod Kumar $^{2}$, Syed Afzal Basha ${ }^{3}$ \\ ${ }^{1} U G$ Student, Dept of Civil Engineering, G Pullaiah College of Engineering \& Technology, Kurnool \\ ${ }^{2} U G$ Student, Dept of Civil Engineering, G Pullaiah College of Engineering \& Technology, Kurnool \\ ${ }^{3}$ Associate Professor, Dept of Civil Engineering, G Pullaiah College of Engineering \& Technology, Kurnool \\ 12azmathulla.gs@gmail.com, 2tvinodkumar98@gmail.com, ${ }^{3}$ syedafzal74@gmail.com
}

\begin{abstract}
Concrete being most utilized development material comprises of solidifying material, fine aggregate, coarse aggregate and required amount of water. Due to rapid growth of infrastructure development activities, the available sources of natural material like sand are getting exhausted at very fast rate. The only way is to search alternative materials. In place of sand, materials like stone dust can be used which possess similar properties like sand. Cement with ground granulated impact heater slag (GGBS) substitution has risen as a significant option in contrast to regular concrete and has quickly drawn the solid business consideration because of its concrete investment funds, vitality reserve funds, and cost reserve funds, natural and financial advantages. In the current test examination an exertion is made to measure the quality of GGBS and stone residue at different substitution levels and assess its efficiencies concerning concrete. The results have demonstrated the positive outcomes with respect to the mechanical properties of concrete.
\end{abstract}

Key words: Mechanical properties, Ground granulated blast furnace slag, Stone dust

\section{INTRODUCTION}

After water, concrete is the most generally utilized substance on Earth. On the off chance that the concrete business was a nation, it would be the third biggest carbon dioxide producer on the planet with up to 2.8 billion tons, outperformed uniquely by China and the US. The material is the establishment of present day improvement, putting rooftops over the heads of billions, bracing our guards against catastrophic event and giving a structure to social insurance, instruction, transport, vitality and industry. Concrete is a composite material made out of fine and coarse total fortified along with a liquid (concrete glue) that solidifies (fixes) after some time. It is a relatively cheap material and has a relatively long life with few maintenance requirements. It is strong in compression. Portland cement is the commonly used type of cement for production of concrete. Today construction cost is extremely high with utilizing regular materials because of inaccessibility of characteristic materials. This issue can be settled by absolute supplanting of cement with various materials which isn't helpful as far as required properties. Because of this confinement of inaccessibility of material which assumes the indispensable job of solid we have just decision of fractional substitution of solid fixings by different materials. The concrete business transmits $\mathrm{CO} 2$ in to the climate which is unsafe to the nature. On the off chance that we can somewhat supplant the cement with the material with attractive properties then we can spare normal material and lessen outflow of $\mathrm{CO} 2$ in to the environment. The primary objective of this study is to select the material which gives desirable properties with concrete. The following are the materials for the partial replacement of conventional cement they are fly ash, bottom ash, metakaolin, zeolite, ground granulated blast furnace slag and etc. These materials are slowly gaining popularity as additives, especially since they can potentially increase strength, decrease density, and prolong durability of concrete. The main objective of this project is to know up to what percentage GGBS can be replaced with cement and up to what percentage Stone dust is replaced with sand.

\section{LITERATURE REVIEW}

B.Sonali, K.Gadpalliwar, R.S. Deotale and R. Abhijeet Narde (2014): In this report for M 40 mix design the mechanical properties are compared by adding quarry dust and GGBS. They concluded that the compressive strength increasers with percentage 
Website: ijetms.in Issue:5, Volume No.4, September-2020 DOI: 10.46647/ijetms.2020.v04i05.016

increase of quarry sand for certain limit. By replacing the cement with GGBS the strength decreases and the workability increases. They concluded that the maximum flexure strength is obtained at the $30 \%$ replacement of GGBS with cement [1].

Rajith M et al (2015): This project focuses on investigating behaviour of M30 concrete by partial replacement of cement and fine aggregate by Ground granulated blast furnace slag (GGBS) and Granulated blast furnace slag (GBS). It is discovered that by halfway supplanting of cement with GGBS and sand with GBS helped in improving the quality of cement contrasted with typical blend concrete [2].

Pavia and Condren: They studied the durability of OPC versus GGBS Concrete on Exposure to Silage Effluent. This examination reasoned that PC composites consolidating GGBS are more solid than those made with PC alone in forceful situations under the activity of acids and salts, for example, those delivered by silage [3].

Hameed and Sekar (2009): They considered the impact of squashed stone residue as fine residue and found that flexural quality increments than the solid with characteristic sand yet the qualities diminishes as the level of smasher dust increments [4].

Lohani et al (2012): Studied the droop esteem increments with increment in rate supplanting of sand with quarry dust. The expansion in dust contents up to $30 \%$ increments the compressive quality of concrete. If the residue content is more than $30 \%$, the compressive quality decreases steadily. Be that as it may, the compressive quality of residue solid keeps on expanding with age for all the level of quarry dust substance [5].

M. Devi et al (2011) carried out an investigation on strength and corrosion resistance behaviour of inhibitors in concrete containing quarry dust as fine aggregate, and concluded that the addition of inhibitors as admixture to concrete was found to lower the permeability and water absorption [6].

\section{EXPERIMENTAL WORK}

\section{A. Materials}

Ordinary Portland cement having 53 grade of Sagar cement brand confirming to B.I.S is used in this project. The cement is tested for its various properties as per IS: 4031-1988 and found to be confirming to the requirements as per IS: 8122 1989. The sand passing through $4.75 \mathrm{~mm}$ size sieve with specific gravity of 2.65 is used in the preparation of specimens and is conforming to Zone-II as per IS: 383-1970. The sand used in this investigation is ordinary river sand which is free from clay, silt and other organic impurities etc. In this project $20 \mathrm{~mm}$ downsize locally available crushed stone obtained from quarries is used as coarse aggregates. The physical properties have been determined as per IS: 2386-1963 and these are having a specific gravity of 2.75 .

Stone Dust, also known as grit, quarry dust, quarry screening, and decomposed granite, is one of the most commonly used stone by-products. The Stone Dust used in this project is obtained from Bethamcharla town of Kurnool district. It is having a specific gravity of 2.5. GGBS is an industrial by product that is diverted from landfill and up-cycled into a commodity product. GGBS is high performance alternative to traditional cement that will increase the technical performance, improve its appearance and minimize its environmental impact.

Generally, quality of water for construction works is same as drinking water. The water shall be clean and shall not contain sugar, molasses or their derivatives, or sewage, oils, organic substances. Alternatively, the water shall be tested in an approved Laboratory for its use in preparing concrete / mortar. For this experimental investigation, M $30 \mathrm{mix}$ is adopted.

\section{B. Method of casting}

Cement, fine aggregate and coarse aggregate were taken in mix proportion 1:1.8:2.4 which correspond to M30 grade of concrete. Fine aggregate is replaced with Quarry dust as 10\%, 20\%, 30\%, 40\% \& 50\%. All the ingredients were dry mixed homogeneously. To this dry mix, required quantity of water was added $(\mathrm{W} / \mathrm{C}=0.44)$ and the entire mix was again homogeneously mixed. This wet concrete was filled the molds which was compacted through hand compaction in three layers and afterward kept into the vibrator for compaction. After the compaction, the examples were given smooth completions. After 24 hours, the specimens were demoulded and transferred to curing tanks where they were allowed to cure for respective 7,28 days. 


\section{International Journal of Engineering Technology and Nanagement Sciences[IJETMSS]}

Website: ijetms.in Issue:5, Volume No.4, September-2020 DOI: 10.46647/ijetms.2020.v04i05.016

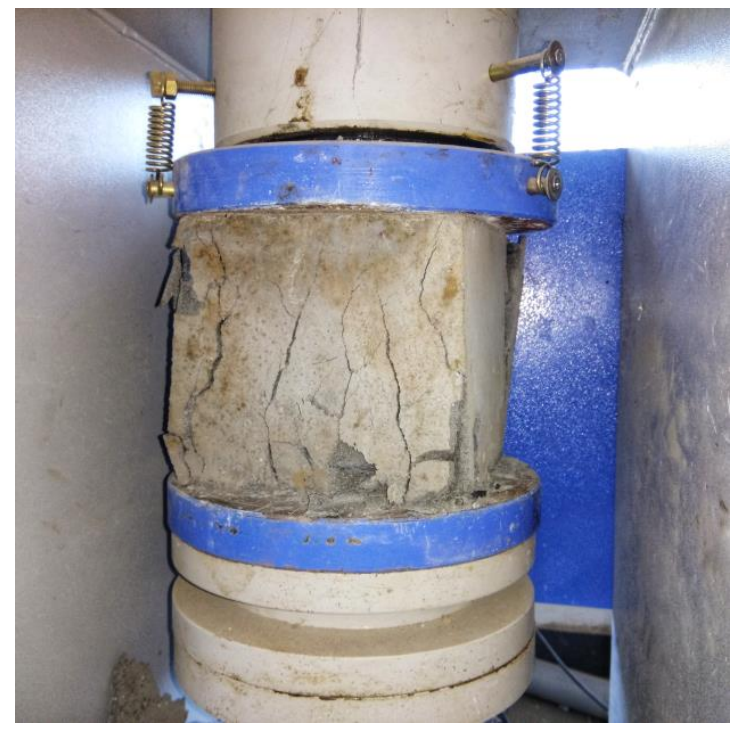

Fig - 1 Testing of cube specimen

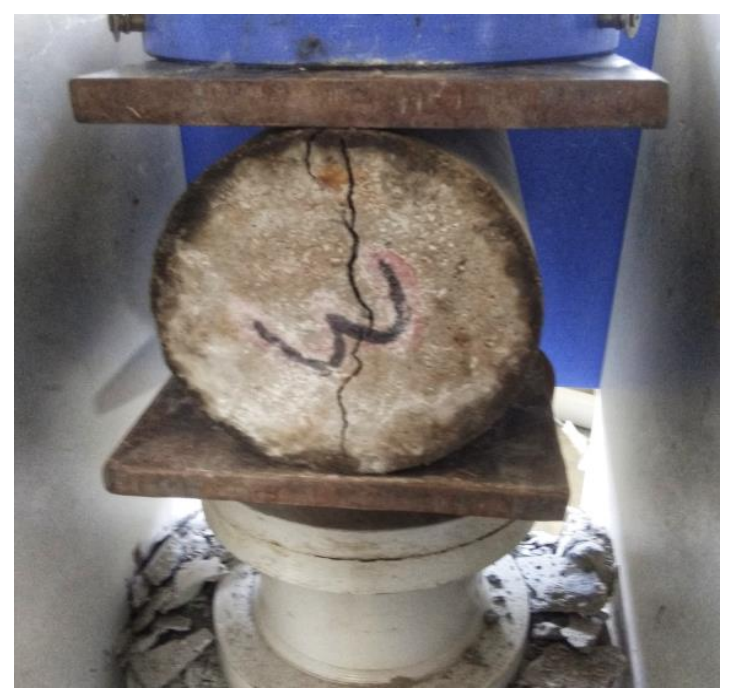

Fig -2 Testing of cylindrical specimen

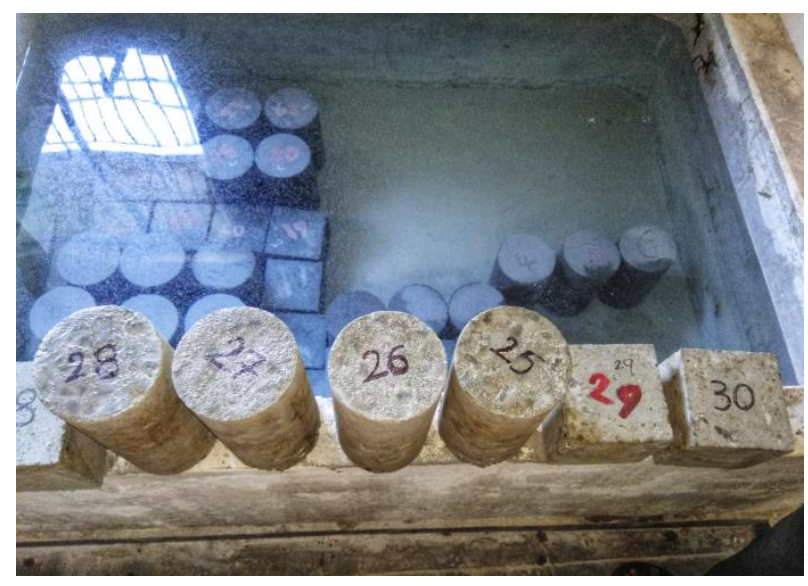

Fig -3 Curing of samples

IV. RESULTS

TABLE I

EXPERIMENTAL TEST RESULTS USING STONE DUST

\begin{tabular}{|c|c|c|c|c|c|}
\hline \multirow{2}{*}{$\begin{array}{c}\text { Mi } \\
\mathbf{x}\end{array}$} & Nomenclature & \multicolumn{2}{|c|}{$\begin{array}{c}\text { Compressiv } \\
\text { e Strength } \\
\text { (MPa) }\end{array}$} & \multicolumn{2}{c|}{$\begin{array}{c}\text { Split } \\
\text { Tensile } \\
\text { strength } \\
\text { (MPa) }\end{array}$} \\
\cline { 2 - 6 } & $\begin{array}{c}\mathbf{7} \\
\text { days }\end{array}$ & $\begin{array}{c}\mathbf{2 8} \\
\text { days }\end{array}$ & $\begin{array}{c}\mathbf{7} \\
\text { days }\end{array}$ & $\begin{array}{c}\mathbf{2 8} \\
\text { days }\end{array}$ \\
\hline M1 & $\begin{array}{c}0 \% \text { SD + 100 \% } \\
\text { sand }\end{array}$ & 23.77 & $\begin{array}{c}37.5 \\
2\end{array}$ & 2.64 & 4.04 \\
\hline M2 & $\begin{array}{c}10 \% \text { SD + 90 \% } \\
\text { sand }\end{array}$ & 20.79 & $\begin{array}{c}36.8 \\
8\end{array}$ & 1.82 & 3.55 \\
\hline M3 & $\begin{array}{c}20 \% \text { SD + 80 \% } \\
\text { sand }\end{array}$ & 21.58 & $\begin{array}{c}38.7 \\
9\end{array}$ & 2.01 & 3.82 \\
\hline M4 & $\begin{array}{c}30 \% \text { SD + 70 \% } \\
\text { sand }\end{array}$ & 22.52 & $\begin{array}{c}39.5 \\
4\end{array}$ & 2.33 & 4.05 \\
\hline M5 & $\begin{array}{c}40 \% \text { SD + 60 \% } \\
\text { sand }\end{array}$ & 23.9 & $\begin{array}{c}42.7 \\
4\end{array}$ & 2.86 & 4.33 \\
\hline M6 & $\begin{array}{c}50 \% \text { SD + 50 \% } \\
\text { sand }\end{array}$ & 22.17 & 40.5 \\
7 & 2.56 & 3.93 \\
\hline
\end{tabular}

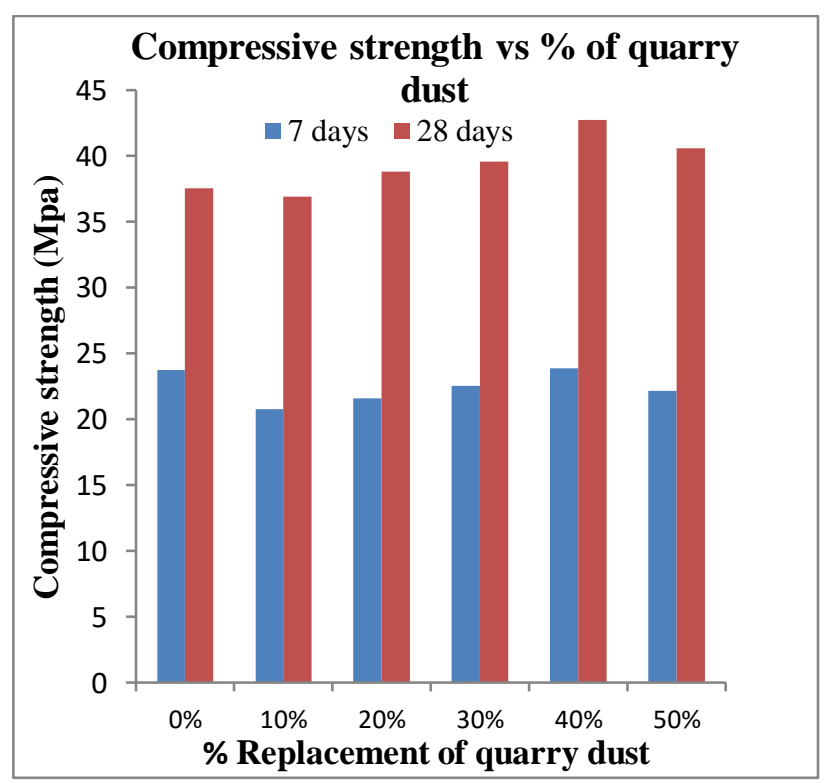




\section{International Journal of Engineering Technology and Management Sciences[IJETMIS]}

Website: ijetms.in Issue:5, Volume No.4, September-2020 DOI: 10.46647/ijetms.2020.v04i05.016

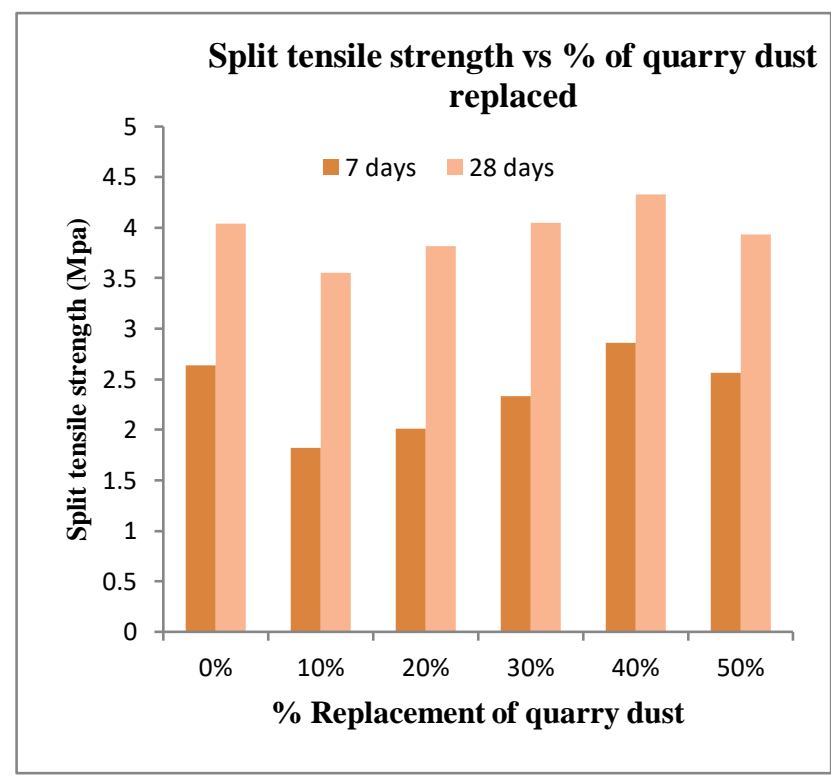

TABLE II

\section{EXPERIMENT TEST RESULTS USING G.G.B.S}

\begin{tabular}{|c|c|c|c|c|c|}
\hline \multirow[t]{2}{*}{ Mix } & \multirow[t]{2}{*}{ Nomenclature } & \multicolumn{2}{|c|}{$\begin{array}{l}\text { Compressiv } \\
\text { e Strength } \\
\text { (MPa) }\end{array}$} & \multicolumn{2}{|c|}{$\begin{array}{c}\text { Split } \\
\text { Tensile } \\
\text { strength } \\
\text { (MPa) }\end{array}$} \\
\hline & & $\begin{array}{c}7 \\
\text { days }\end{array}$ & $\begin{array}{c}28 \\
\text { days }\end{array}$ & $\begin{array}{c}7 \\
\text { day } \\
s\end{array}$ & $\begin{array}{c}28 \\
\text { days }\end{array}$ \\
\hline M7 & $\begin{array}{c}(40 \% \text { S.D }+60 \\
\% \text { sand })+(0 \% \\
\text { G.G.B.S + } 100 \% \\
\text { Cement })\end{array}$ & 23.9 & $\begin{array}{l}42.7 \\
4\end{array}$ & $\begin{array}{c}2.8 \\
6\end{array}$ & 4.33 \\
\hline M8 & $\begin{array}{c}(40 \% \text { S.D + } 60 \\
\% \text { sand })+(15 \% \\
\text { G.G.B.S + } 85 \% \\
\text { Cement })\end{array}$ & $\begin{array}{c}20.6 \\
7\end{array}$ & $\begin{array}{l}41.6 \\
7\end{array}$ & $\begin{array}{c}2.5 \\
6\end{array}$ & 4.23 \\
\hline M9 & $\begin{array}{c}(40 \% \text { S.D }+60 \\
\% \text { sand })+(30 \% \\
\text { G.G.B.S }+70 \% \\
\text { Cement })\end{array}$ & 22.9 & $\begin{array}{l}43.7 \\
1\end{array}$ & $\begin{array}{c}2.8 \\
4\end{array}$ & 4.44 \\
\hline $\begin{array}{c}\text { M1 } \\
0\end{array}$ & $\begin{array}{c}(40 \% \text { S.D }+60 \\
\% \text { sand })+(45 \% \\
\text { G.G.B.S }+55 \% \\
\text { Cement })\end{array}$ & $\begin{array}{c}25.6 \\
1\end{array}$ & 46.5 & $\begin{array}{c}3.0 \\
4\end{array}$ & 4.75 \\
\hline $\begin{array}{c}\text { M1 } \\
1\end{array}$ & $\begin{array}{l}(40 \% \text { S.D + } 60 \\
\% \text { sand })+(60 \%\end{array}$ & $\begin{array}{c}23.8 \\
9\end{array}$ & $\begin{array}{l}44.5 \\
8\end{array}$ & $\begin{array}{c}2.7 \\
6\end{array}$ & 4.54 \\
\hline
\end{tabular}

\begin{tabular}{|l|c|l|l|l|l|}
\hline & $\begin{array}{c}\text { G.G.B.S + 40 \% } \\
\text { Cement })\end{array}$ & & & & \\
\hline
\end{tabular}
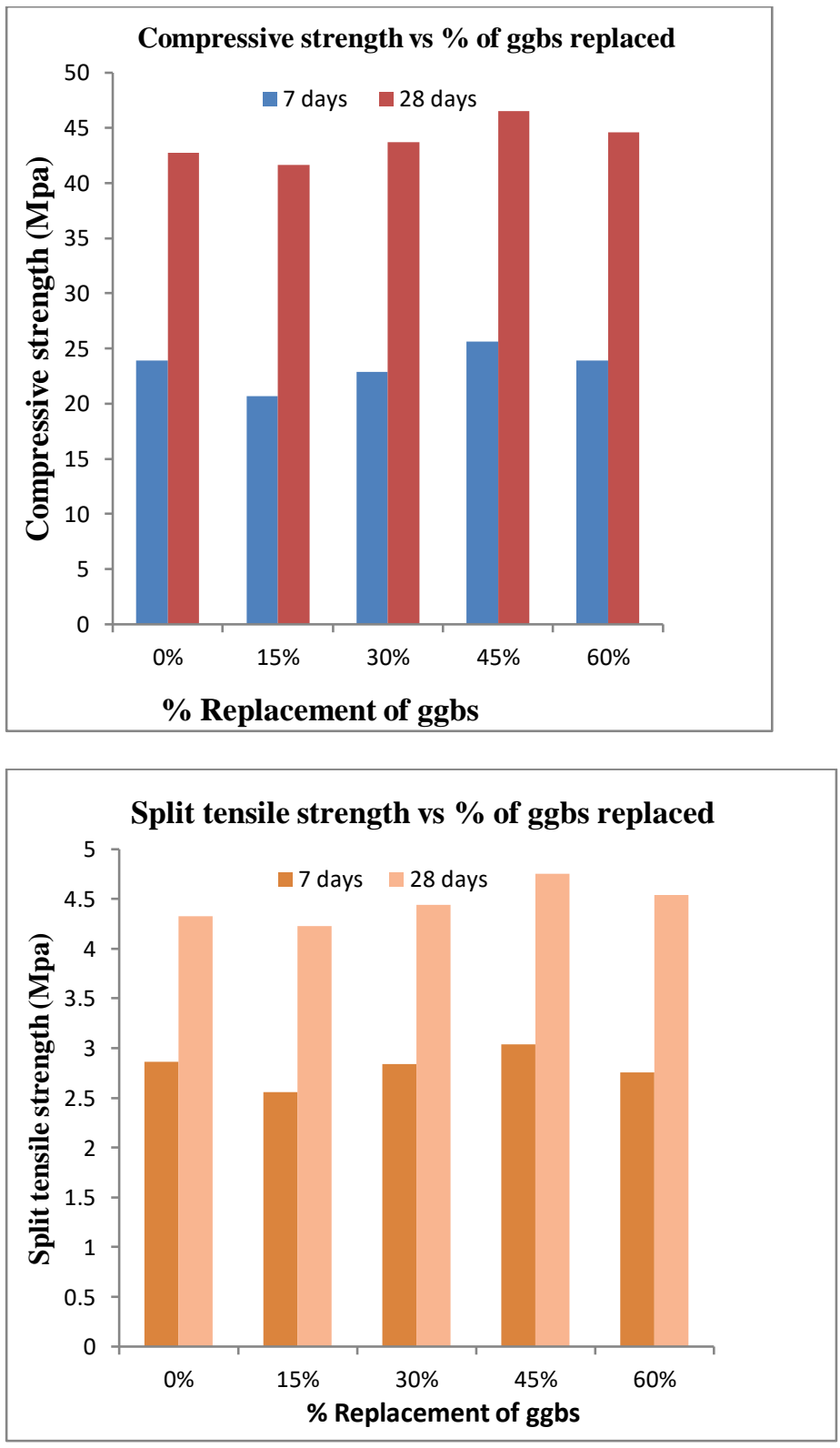

\section{CONCLUSION}

$>$ When fine aggregate was replaced by Quarry dust waste in the percentages of $0 \%$, $10 \%, 20 \%, 30 \%, 40 \%$ and $50 \%$ then both compressive strength and tensile strength of the specimens increased up to $40 \%$ replacement and there after decreased at $50 \%$ replacement.

$>$ The workability of concrete decreased 
Website: ijetms.in Issue:5, Volume No.4, September-2020 DOI: 10.46647/ijetms.2020.v04i05.016

gradually when replacement of fine aggregate with Quarry dusts waste ranges from $0 \%$ to $50 \%$.

$>$ The optimum percentage of Quarry dust waste for fine aggregate replacement is $40 \%$.

$>$ Starting from $0 \%$ to $60 \%$ replacement of cement with G.G.B.S, up to $45 \%$ of replacement level of cement with G.G.B.S, there is an increase in both compressive strength and tensile strength and at $45 \%$ to $60 \%$ both compressive strength and tensile strength values decreased.

$>$ From the experimental investigation it is concluded that G.G.B.S can be replaced up to $45 \%$ in place of cement and optimum percentage of G.G.B.S is $45 \%$.

\section{REFERENCES}

[1] B. Sonali, K. Gadpalliwar, R. S. Deotale, Abhijeet R. Narde (2014):- "To study the partial replacement of cement by GGBS \&RHA \& Natural sand by Quarry sand in concrete", IOSR Journal of Mechanical and Civil Engineering (IOSR-JMCE), V-11, P-69-77,2014.

[2] Rajith M (June-2015):-“Performance of Concrete with Partial Replacement of Cement and Fine Aggregate by GGBS and GBS".

[3] S. Pavia and E. Condren:- Study of the Durability of OPC versus GGBS Concrete on Exposure to Silage Effluent\| journal of materials in civil engineering asce / April 2008 / 313-319.

[4] Hameed M.S. and Sekar A.S.S. (2009):- Quarry dust as replacement of fine aggregate in concrete. ARPN J. Engg. Appl. Sci. 4(4): 83-89.

[5] Lohani (2012):- Optimum Utilization of Quarry Dust as Partial Replacement of Sand in Concrete. International Journal of Applied Sciences and Engineering Research. 1. 391-404.

[6] M. Devi (2011):- "Analysis of strength and corrosion resistance behaviour of inhibitors in concrete containing quarry dust as fine aggregate", ARPN Journal of Engineering and Applied Sciences Vol 6, No. 11, pp. 124 -135, November 2011. 
International Journal of Engineering Technology and Management Sciences[IJETMS]

Website: ijetms.in Issue:5, Volume No.4, September-2020 DOI: 10.46647/ijetms.2020.v04i05.016 